\title{
A Panel Analysis of Trade Gravity between Pakistan and South Asian Countries
}

\author{
Waheed Ullah Jan \\ Ph.D., Research Scholar, Department of Economics, Gomal University \\ Dera Ismail Khan, Pakistan, e-mail: janwaheed77@gmail.com
}

\section{Mahmood Shah}

Associate Professor, Department of Economics, Gomal University

Dera Ismail Khan, Pakistan, e-mail: moodishahji@yahoo.com

\begin{abstract}
This paper attempts to examinePakistan's trade patterns with South Asian countries by using a gravity model of trade. The main objective of the study is to quantify the long-run impacts of gravity variables. To achieve this objective, a panel data set for the period 2003 to 2017 has been used. Based on the mixed evidence of the results of panel unit root tests, Pooled Mean Group (PMG) and Panel Dynamic Ordinary Least Square (DOLS) techniques are applied. The outcome of the PMG and Panel DOLS models justifies the theoretical background of the gravity model and suggests that all the basic gravity variables haveusual signs. The RGDPs and population ofboth Pakistan and the partner country have a positive impact on their bilateral trade. On the other hand,the distance between the two trading countries and the exchange rate have a negative impact on bilateral trade.The uniqueness of this study is that it measures the impacts of qualitative variables along with basic gravity variables. Language similarities and common borders have a positive impact on bilateral trade. Pakistan has borders with India and Afghanistan, but their trade relations are not worth mentioning. The military conflicts between Pakistan and India, andthe political suspicions between Pakistan and Afghanistan hinder their trade relations.
\end{abstract}

Keywords: South Asia, Pakistan, gravity model, exchange rate, population

JEL: F12, F15, F42, F53 


\section{Introduction}

South Asia consists of eight self-governing states (India, Pakistan, Bangladesh, Nepal, Bhutan, the Maldives, Sri Lanka, and Afghanistan). A huge portion of the world's population lives in South Asia. These countries are economically very backward, however, and agriculture is the main occupation. Trade among these countries is not worth mentioning. They are heavily dependent on foreign markets, they get very little from international trade, and they always face trade deficits. The area is characterized by poverty, and the majority of people live below the poverty line. Each country has its own characteristics, with differences in consumption behavior, product manufacturing, tax structure, and investment structure. These differences provide a base for trade in the region.

South Asia has great importance in global politics due to its geographical location. The region has the world's attention due to the permanent stress on the line of control and military conflicts between India and Pakistan. However, this is only one side of the coin. On the other side, the region offers an authentic scenario of economic interests, joint development, and democracy. Since 1990, the economic policies of the South Asian countries have changed enormously; in particular, Bangladesh, India, Pakistan, and Sri Lanka have revised their trade policies. They liberalized their trade and started to open their economies to international trade.

South Asian countries have signed various trade agreements to liberalize their trade. The first step towards trade liberalization was the Regional Trade Agreement (RTA). The RTA provided the basis for SAARC Preferential Trading Arrangement (SAPTA), which was signed in 1993 and implemented in 1995. The main objective of this agreement was to encourage mutual trade among South Asian countries. SAPTA was later changed into the South Asian Free Trade Agreement (SAFTA).

The South Asian Free Trade Area: SAFTA was signed in January 2004 and implemented in January 2006. All the member countries agreed to follow the agreement. In the first phase, the member countries were legally bound to reduce their customs duty. In this regard, Pakistan, India, and Sri Lanka were asked to reduce their customs duties. In the next phase, Bhutan, Bangladesh, Nepal, Afghanistan, and the Maldives will decrease their customs duties.

The main objective of this agreement was to bring transparency and create competition in mutual trade. They emphasized the mobility of labor, a reduction in transportation cost, and capital accumulation. They also decided to reform the services sector and improve the energy sector.

The Afghan-Pak Transit Trade Agreement (APTTA): This agreement was signed by the two countries in 2010 and implemented in 2011. The main objectives were to stop smuggling, to ensure the smooth flow of commodities, and to protect Pakistan's strategic interests. Moreover, Pakistan will allow Afghanistan to trade with India through the Wagha Border, with Pakistan providing infrastructure and security. Goods will be transported through open trucks and containers. However, India will not be allowed to export goods through Wagha Border. 
The Pakistan and Sri Lanka Free Trade Agreement (FTA): This agreement has been operational since 2005. In the light of this agreement, both countries will give permission to reach each other's markets by granting tariff concessions. After the implementation of this agreement, Pakistan is able to get concessions on 102 foodstuffs in the Sri Lankan markets. These products consist of fruits, fish, and spices. Meanwhile, Sri Lanka is able to export 206 duty-free goods to Pakistan, including coffee, black pepper, and dry fruits.

The India-Sri Lanka Free Trade Agreement (ISLFTA): This agreement was signed in 1998 and came into practice in 2000. According to this agreement, tariff concession will be given from each side on specific commodities. Both countries prepared two types of lists. One is a positive list, which means full concession. The second is a negative list, which means no concession. The criteria for the recommendation of tariff-free and not tariff-free goods are prepared under the FTA rules.

South Asian countries have gained a lot through the creation and diversification of trade. After the implementation of SAFTA, about US\$ 8 billion was achieved from the total manufactured goods under the full tariff liberalization (Kumar 2005). Regional trade potential and economic integration of South Asia is amazing. According to Kumar (2005), mutual trade in the region would be three times bigger than the existing level if the unofficial flow of trade was considered. Official trade can be increased up to the level of US $\$ 36$ billion by 2020 . He further says that through SAFTA, trade diversion effects can make it easy for the small countries to reach the big markets of developed economies. Ultimately, smaller economies like Nepal, Bhutan, Bangladesh, and the Maldives will get more benefits from trade than comparatively larger economies like Pakistan and India (Rispens 2009).

To compare the reality with other regions, the trade performance of South Asian countries has been very poor in world trade during the last 20 years. Over the past 20 years, exports from the region grew only twofold, to reach approximately US\$100 billion, while within the same period, East Asian exports were ten times greater (Newfarmer and Pierola 2006). This is the sign of the limited trade integration between South Asia and its trading partners in the world. Their mutual trade collaboration is very limited. The intra-regional trade ratio to GDP is about $33 \%$ of South Asia's GDP, whereas it is $71 \%$ in the East Asian nations (Wilson and Otsuki 2007).

The main objective of this research paper is to highlight the trade pattern of Pakistan with other South Asian countries. The other objectives of the study are: (1) To analyze the degree of trade integration between Pakistan and its South Asian trading partners. (2) To quantify the long-run impacts of basic gravity variables. (3) To discover the short-run and long-run impacts of a common border and common language on trade relations between Pakistan and the South Asian countries.

The rest of the paper is arranged as follows: the second section contains relevant literature to the study. The third section consists of the research methodology. The fourth section is furnished with empirical results, and in the last section, conclusions are drawn. 


\section{Literature review}

The gravity model of trade is considered the workhorse for empirical analysis in bilateral trade. In this section, past research studies in which the gravity model of trade was used with new variables are discussed.

Panda and Kumaran (2016) researched India-China trade relations using the gravity model of trade. The results were obtained by a random-effects model and a panel regression model. Their findings suggest that the trade flows of both countries are greater with countries that are closer to them. India's trade flows are influenced by its GDP growth rate and low per capita income. Similarly, China's trade is highly influenced by a common language and the per capita income of its trading partners. GDP growth rate and common language have a positive impact on their bilateral trade.

Wang (2016) researched 80 countries for the period 2000 to 2013 using a balanced panel data set. He fitted the data in a gravity model of trade and used the Poisson pseudo maximum likelihood (PPML) technique for estimation. The results suggest that the GDPs of importer countries have a statistically positive impact, while distance has a negative impact on bilateral trade. So, both variables follow the theoretical background of the gravity variables.

Waheed and Shujaat (2015) studied the trade relations of Bahrain and its 31 trading partners. They used a panel data set for the period 1994 to 2013 . The results were obtained by an augmented gravity model using panel generalized least squares (GLS) estimation technique. Based on their empirical results, they concluded that the relative price ratio and foreign reserves of the trading partners are important in determining the export flow of Bahrain. The dummy variables for FTA and GCC (Gulf Cooperation Council) are also crucial factors in determining the trade flow. The basic variables of the gravity model have the usual effects.

Mohmand and Wang (2013) conducted a study to explore the factors affecting exports of Pakistan through a gravity model. The authors collected data on 142 countries for the period 1995 to 2011. They furnished the gravity model with dummy variables like a common language, common religion, and free trade agreements along with basic variables (GDPs and distance). From the empirical findings, it was concluded that common language and common religion have no relation with Pakistan's bilateral trade. Furthermore, they explained that importer and exporter GDPs are very important for two-sided trade. It was recommended that Pakistan divert its trade towards countries that are nearest to it.

Malik and Chaudhry (2012) investigated the main reasons for Pakistan's imports from Asian economies in the light of the 1990s import policy. The researchers fitted a gravity model and applied the OLS technique to panel data for the period 19962006. The empirical work concentrated on macroeconomic variables and their behavior in trade gravity. The estimated findings indicate that the GDP of Pakistan and its trading partner has a positive impact on imports, while the exchange rate has a nega- 
tive impact. From the results, it was concluded that GDP, exchange rate, and free trade agreements are the main factors of Pakistan's imports from Asian countries.

Akhter and Ghani (2010) examined the gains from regional trade and the trade potential of SAARC countries in the light of SAFTA. They estimated a gravity model to measure the trade flows among South Asian countries. The estimation techniques were applied on panel data, and the time period selected was from 2003 to 2008 . The empirical results suggested that SAFTA can play a significant role in promoting bilateral trade in the SAARC region. The researchers also explained that all the member countries of SAARC will reap the trade benefits if SAFTA is implemented. They emphasized that in this respect, the role of three major partners (Sri Lanka, Pakistan, and India) is very important.

Wang et al. (2010) conducted a study on the trade structure of nineteen OECD countries between 1981 and 1999 and applied an augmented gravity model for estimation. Based on the empirical results, they concluded that the distance between the economic centers of these countries negatively affects bilateral trade among them. Moreover, it was declared that FDI and FDI stock, GDP, and local technology are no less important. They argued that these variables have a positive impact on the bilateral trade of OECD countries.

The previous research studies indicate that the gravity model of trade is commonly used to estimate international trade. However, very little work has been done on the trade patterns of south Asian countries. Most researchers analyzed only large countries in the region. In this paper, an attempt is made to analyse Pakistan's bilateral trade with all South Asian countries by using the gravity model of trade.

\section{Research methodology}

\section{Study area}

The study concentrates on Pakistan's bilateral trade with South Asian countries. They were selected because they are consistent trading partners of Pakistan. Pakistan and India share a long border, although there is always unrest on the line of control (LOC) and political conflicts; yet they have an opportunity to enhance their trade activities. Similarly, Afghanistan lies on the border with Pakistan. Other countries of the region also have close relations with Pakistan. Nepal and Bhutan are small countries of the region whose markets Pakistan can access, while Sri Lanka and Bangladesh are no less important for trade. 


\section{Data description and sources of data}

For the empirical analysis, panel data was used for fifteen years, from 2003 to 2017. All the data are taken on a yearly basis. Countries' individual and bilateral import and export data is taken from the International Trade Center (ITC), based on UN Comtrade statistics (2017). Data about macroeconomics variables (population, RGDP, and exchange rate) were obtained from the World Development Indicators (WDI 2017). The distance between trade centers, normally the capital cities of the trading countries, is taken and calculated from the Great Circle Distance online. All the data were converted into USD millions. Data on the population for all countries is also presented in millions. The exchange rate between counter partners is changed into USD, and the Pakistani currency is linked to the USD because payments between Pakistan and its trading partners are made in USD.

The data was fitted and analyzed by the statistical package "Eviews9" with help from STATA9. The total bilateral trade variable $T T_{i j}$ was generated by the summation of Pakistan's exports and imports to and from each counter partner. Common language and common border were incorporated as dummy variables. All the variables are log-transformed except the dummy variables. Throughout the study, seven variables-one independent and six dependents-are discussed for eight countries, including Pakistan.

\section{Model specification}

The gravity model has gained in importance in recent years in international trade. It was used for the first time by Tinbergen (1962) and Pöyhönen (1963) for their empirical studies. Its first implication in international trade was to find the causes of bilateral trade. In accordance with Newton's law of universal gravitation, i.e., two items attract each other in proportion to their masses and inversely proportional to the square of the distance between them, two countries will trade each other according to their GDP sizes and proximity. Put simply, two- sided trade will increase in direct proportion to their economic magnitude and will decrease with every increase in distance.

Krugman et al. (2012) formulated the gravity model of trade as:

$$
T_{i j}=A \frac{Y_{i}^{a} \times Y_{j}^{b}}{D_{i j}^{c}}
$$

Taking natural log to both sides

$$
\ln T_{i j}=A+a \ln Y_{i}+b \ln Y_{j}-c \ln D_{i j}+\varepsilon_{i j t}
$$


where $T_{i j}=$ Total trade volume between country $i$ and country $j$ (summation of imports and exports). $A=$ Constant (gravitational proportionality). $Y_{i j}=$ GDPs of country $i$ and country $j$ (economic mass). $D_{i j}=$ Distance between two countries' capital cities or trade centers. $\mathrm{a}, \mathrm{b}$, and $\mathrm{c}=$ parameters to be estimated. $\varepsilon_{i j t}=$ Error term. Equation (3) indicates that trade between two countries takes place due to three factors, their respective GDPs (GDP ${ }_{i}$ and GDPj) and the distance between them.

Krugman et al. (2012) believe that the gravity model is applicable in bilateral trade because high-income countries spend a huge share of their income on imports. They attract other countries to purchase goods from them because they have a large variety of goods and a vast home market. So, the larger the economy, the greater the trade.

The model is modified and augmented with some new variables:

$$
\begin{gathered}
\operatorname{lnTT}_{i j t}=\alpha+\beta_{1} \ln R G D P_{i j t}+\beta_{2} \ln P O P_{i j t}+\beta_{3} \ln E X R_{i j t}+\beta_{4} \ln D I S T_{i j}+ \\
+\beta_{5} C B O R+\beta_{6} C L A N G+U_{i j t}
\end{gathered}
$$

where

$\alpha=$ intercept,

$U_{i j t}=$ omitted variables or unobserved factors that influence bilateral trade,

$\beta_{i}=$ coefficients $\left(\beta_{1}, \beta_{2}, \ldots, \beta_{6}\right.$ represent elasticities of variables),

$T T_{i j t}=$ Total trade volume between country $i$ and country $j$ in period $t$,

$R G D P_{i j t}=$ Product of Real Gross Domestic Product of country $i$ and country $j$ in period $t$,

$P O P_{i j t}=$ Product of population of country $i$ and country $j$ in time period $t$,

$E X R_{i j t}=$ Bilateral exchange rate between country $i$ and country $j$ in time period $t$,

$D I S T_{i j}=$ Distance between country $i$ and country $j$.

Note: Country $i$ is always Pakistan and country $j$ is the partner country.

Dummy variables of the study

CBOR: Common Border (1if the border is common, 0 otherwise).

CLANG: Common Language (1if the language is common, 0 otherwise).

\section{Analytical techniques}

\section{Panel Unit Root Test}

Panel data usually have the problem of stationarity. So, it is necessary to remove this problem from the data; otherwise, it will give spurious results. To detect the problem of stationarity, various panel unit root tests are used. For the current study, the LLC Test (Levin, Lin, and Chu 2002) and IPS Test (Im, Pesaran, and Shin 2003) are used 
to check the stationarity and order of integration of the variables. The LLC test generated by Levin et al. (2002) is a simplified form of the ADF (augmented Dickey-Fuller) test and is frequently used for panel data. Both of these tests are discussed below.

\section{LLC Panel Unit Root Test}

The LLC panel unit root test constitutes the null hypothesis: every individual time series in the panel data has a unit root (not stationary), and the alternative hypothesis is: every individual time series in the panel data has no unit root (stationary). The customized shape of the ADF test (LLC Test) is presented below:

$$
\Delta y_{i t}=\rho_{i} y_{i t-1}+\sum_{j=1}^{p i} \theta_{i j} \Delta y_{i t-j}+\varnothing_{i} z_{i t}+\varepsilon_{i t}
$$

where $\rho_{i}=$ the coefficient of autoregressive (AR), $z_{i t}=$ vector of deterministic variables (including fixed effects, linear time trends and time dummies) that capture cross-sectional heterogeneity, and $\varnothing_{i}=$ vector of the coefficients.

The limitation of the LLC test is that it requires long time periods; otherwise, its application will be tricky, and it will give weak results.

\section{IPS Panel Unit Root Test}

The LLC test is discouraging because it needs a large number of observations and homogeneity in all cross-sections. Im et al. (2003) considered homogeneity and designed a separate panel unit root test for heterogeneity. Their test is also based on individual cross-section ADF tests. They repeated the problem of heterogeneity in the panel data and tried to tackle this problem by taking the average of all cross-sections and then applying the ADF test individually. They suggested the null hypothesis as: there is no unit root in every time series of the panel $\left(H_{0}: \rho_{i}=0\right.$ for all $\left.i\right)$, and set the alternative hypothesis as: there is a unit root in some time series of the panel $\left(H_{a}: \rho_{i}<0\right.$ for at least one $i$ ).

The IPS test can be calculated as the average of the ADF statistic for individual cross-sections:

$$
\bar{t}=\frac{1}{N} \sum_{i=1}^{N} t_{\rho i}
$$

where $t_{\rho i}=$ the average of the ADF statistic for testing the null hypothesis. The IPS test indicates that $\bar{t}$ is normally distributed $\mathrm{N}(0,1)$. The IPS test statistic equation is given below: 


$$
t_{I P S}=\frac{\sqrt{N}\left(\bar{t}-\frac{1}{N} \sum_{i=1}^{N} E\left(t_{i T} \mid \rho_{i}=0\right)\right)}{\sqrt{\frac{1}{N} \sum_{i=1}^{N} \operatorname{var}\left(t_{i T} \mid \rho_{i}=0\right)}} \Rightarrow N(0,1)
$$

When $\mathrm{T} \rightarrow \infty$ and also $\mathrm{N} \rightarrow \infty$ consecutively. The IPS test demonstrates that if a large number of observations are chosen for the basic ADF test, then applying thet-bar statistic (IPS test) for small sample observation is a logically more suitable option for detecting unit root than the LLC test (Baltagi 2008).

\section{Panel Cointegration Tests}

Baltagi (2008) investigated whether a cointegration test is able to answer the question of whether long-run relationships actually exist in the macroeconomic variables included in the model or not. For the current study, Pedroni's $(1999 ; 2004)$ panel cointegration test was selected to capture the long-run properties of cointegrating variables.

Pedroni's (1999) cointegration equation is given as below:

$$
y_{i t}=\alpha_{i}+\beta_{i} t+\lambda_{1 i} x_{1 i}+\lambda_{2 i} x_{2 i}+\lambda_{3 i} x_{3 i}+\ldots+\lambda_{m i} x_{m i}+e_{i t}
$$

where $i$ is the number of cross-sections $(i=1,2,3, \ldots, \mathrm{N}), t$ is the time period $(t=1,2,3, \ldots, \mathrm{T})$, $m$ indicates (xs) the explanatory variables $(m=1,2,3, \ldots, \mathrm{M})$ and $e_{i t}=\rho_{i} e_{i t-1}+\varepsilon_{i t}$.

In the same equation, = the intercept, showing individual-based effects (fixed-effects) that change for every cross-section, $\beta_{i}=$ time effect variations in each cross-section and $\lambda_{1 i}, \lambda_{2 i}, \lambda_{3 i}, \ldots \ldots, \lambda_{m i}$ are the coefficients of the explanatory variables.

Pedroni classified the test statistics into two groups; one is within-group, which measures homogeneity, and the other is between-group which measures the heterogeneity of the AR component. Pedroni applied this to the seven panels and set the null hypothesis of no cointegration. Among them, four were within-group (pooled statistics), also known as panel test statistics, and the remaining three were between-group, encouraging the heterogeneity of the AR term. Kao's (1999) test is based on the equation below:

$$
y_{i t}=\alpha_{i}+x_{i t}^{\prime} \beta+e_{i t}
$$

where $\alpha_{i}=$ the intercept (fixed effects), $y_{i t}=$ the dependent variable and is stationary at the first difference and, $x_{i t}^{\prime}=$ the independent variable, which is also stationary at first difference. To test the null hypotheses of no cointegration, Kao (1999) suggested the DF and $\mathrm{ADF}$ unit root tests for the residual term $\left(e_{i t}\right)$. These tests are calculated on the basis of fixed-effects residuals $\left(e_{i t}=\rho e_{i t-1}+v_{i t}\right)$. Hence, the null hypothesis will be written as: $H_{0}: \rho=1$ (no cointegration). 


\section{Estimating the Pooled Mean Group (PMG) Estimator}

Persaran et al. (1999) introduced a new technique, called 'the PMG estimator, for estimating non-stationary dynamic heterogeneous panels. It depends upon the amalgamation of pooling and the averaging of coefficients across groups (Frank 2007). The procedure adopted by Persaran et al. (1999) follows an autoregressive distributed lag (ARDL) model. The dynamic panel specification is as follows:

$$
y_{i t}=\sum_{j=1}^{p} \varphi_{i j} y_{i, t-1}+\sum_{j=1}^{q} \delta_{i j} x_{i, t-j}+\mu_{i}+\varepsilon_{i, t}
$$

where $i=1,2,3, \ldots, \mathrm{N}$ (number of groups); $t=1,2,3, \ldots, \mathrm{T}$ (number of periods); $X_{i t}=$ $k \times 1$ vector of explanatory variables; $\delta_{i j}=k \times 1$ coefficient vectors; $\varphi_{i j}=$ scalars and $u_{i}$ is the group-specific effect. Fixed explanatory variables and time trends are also included. The essential characteristic of the cointegrated variables is their reaction towards any deviation from the long-run equilibrium. The PMG estimator explains the short-run dynamics of the variables in the model by estimating an error correction equation of the ARDL model. The equation is outlined below:

$$
y_{i t}=\varphi_{i}\left(y_{i, t-1}-\theta_{i}^{\prime} x_{i t-t}\right)+\sum_{j=1}^{p-1} \lambda_{i j}^{*} \ddot{\mathrm{A}} y_{i, t-1}+\sum_{j=1}^{q-1} \delta_{i j}^{t^{*}} \ddot{\mathrm{A}} x_{i, t-j}+\mu_{i}+\varepsilon_{i t}
$$

where $\varphi_{i}=$ error-correcting speed of the adjustment term. If $\varphi_{i}=0$, then there would be no confirmation of a long-run relationship. It is assumed that if the variables affect the long-run equilibrium, then this parameter is likely to be negatively significant. The most important terms of the above equation are $\theta_{i}^{\prime}$ and $\delta_{i j}^{t^{*}}$. The former $\left(\theta_{i}^{\prime}\right)$ represents long-run relationships between the variables (i.e., long-run coefficients), while the later $\left(\delta_{i j}^{t^{*}}\right)$ illustrates the short-run relationships (Frank 2007).

\section{The Panel Dynamic Ordinary Least Squares (DOLS) Estimator}

Kao and Chiang (1999) used the panel dynamic OLS technique to measure the long-run relationships between the variables. They found that the DOLS surpasses the fixed effects (OLS) estimator and tends to be more capable in cointegrated panel regressions (Fidrmuc 2009; Baltagi 2008). The DOLS estimator is actually a panel extension of the method initially presented by Saikkonen (1991) and Stock and Watson (1993) for time series analysis. The basic DOLS specification is given as below:

$$
y_{i t}=\alpha_{i}+\beta^{\prime} x_{i t}+\sum_{j=-q}^{q} \delta_{i j} \ddot{\mathrm{A}} x_{i, t+j} \varepsilon_{i t}
$$


where $X_{i t}=$ explanatory variables, $\beta$ = coefficient (estimated long-run impact), $q=$ lags of the first differenced data and $\delta_{i j}=$ related parameters. In this study, we employ the following DOLS gravity equation:

$$
\operatorname{lnTT}_{i j t}=\alpha_{i}+\beta M_{i j t}+\sum_{k=-m}^{m} \psi_{i j} \ddot{\mathrm{A}} M_{i j, t+k}+\chi_{1} C B O R_{i j t}+\chi_{2} C L A N G_{i j t}+\varepsilon_{i j t}
$$

where $M_{i j t}$ is the vector of integrated regressors, which consists of the logs of GDPs, population, real exchange rate, and distance, and $\sum_{k=-m}^{m} \psi_{i j} \ddot{\mathrm{A}} M_{i j, t+k}$ is the summation of leads and lags of the differenced explanatory variables. By including the leads and lags of the differenced independent variables as additional explanatory variables in the gravity equation, the panel DOLS creates a probable endogeneity bias as well as the problem of autocorrelation. Standard errors are used to regulate interpretable test statistics with the usual restrictive distributions.

\section{Results and discussion}

\section{Results of Panel Unit Root Tests}

It is essential to check the integrational properties or stationarity of the time-variant variables included in the model. The results are obtained through the LLC and IPS panel unit root tests. To decide the country-specific lag length for the ADF regressions, the Schwarz-Bayesian Information Criterion (BIC) is used with a maximum lag of 2. The results of the LLC and IPS tests are presented in Table 1.

The results of the LLC panel unit root test indicate that all the variables, i.e., the product of the RGDP (RGDPijt), the product of the population (POPijt), and the exchange rate (EXRijt) are non-stationary at level with constant (individual intercept), demonstrating the existence of a unit root in these variables. Meanwhile, total bilateral trade (TTijt) can be seen as stationary in the same column. Now, the deterministic trend is included in the model, but again a problem arises. This time, three variables (TTijt, RGDPijt and EXRijt) are stationary, but one variable (POPijt) is non-stationary. With the same conditions (with and without time trend), the IPS test is applied to detect the unit root in the variables. This time, the problem is with total bilateral trade (TTijt). The results demonstrate that three variables (RGDPijt, POPijt, and EXRijt) are non-stationary, and one variable (TTijt) is stationary at level with individual intercept. When the time trend is included, all variables become non-stationary, indicating the unit root. 
Table 1. Panel Unit Root Tests Results

\begin{tabular}{|c|c|c|c|c|c|c|c|c|}
\hline \multirow[b]{3}{*}{ Variables } & \multicolumn{4}{|c|}{ LLC Test } & \multicolumn{4}{|c|}{ IPS Test } \\
\hline & \multicolumn{2}{|c|}{ Level } & \multicolumn{2}{|c|}{ First Difference } & \multicolumn{2}{|c|}{ Level } & \multicolumn{2}{|c|}{ First Difference } \\
\hline & Constant & $\begin{array}{c}\text { Constant } \\
\text { with } \\
\text { Trend }\end{array}$ & Constant & $\begin{array}{c}\text { Constant } \\
\text { with } \\
\text { Trend }\end{array}$ & Constant & $\begin{array}{c}\text { Constant } \\
\text { with } \\
\text { trend }\end{array}$ & Constant & $\begin{array}{c}\text { Constant } \\
\text { with } \\
\text { trend }\end{array}$ \\
\hline $\ln T T_{i j t}$ & $\begin{array}{c}-4.189 \\
(0.000)\end{array}$ & $\begin{array}{c}-1.791 \\
(0.036)\end{array}$ & $\begin{array}{c}-5.540 \\
(0.000)\end{array}$ & $\begin{array}{l}-6.173 \\
(0.000)\end{array}$ & $\begin{array}{c}-1.926 \\
(0.027)\end{array}$ & $\begin{array}{c}0.612 \\
(0.730)\end{array}$ & $\begin{array}{c}-4.547 \\
(0.000)\end{array}$ & $\begin{array}{l}-4.185 \\
(0.000)\end{array}$ \\
\hline $\ln R G D P_{i j t}$ & $\begin{array}{c}-1.540 \\
(0.061)\end{array}$ & $\begin{array}{c}-3.193 \\
(0.007)\end{array}$ & $\begin{array}{c}-2.827 \\
(0.002)\end{array}$ & $\begin{array}{r}-1.686 \\
(0.045)\end{array}$ & $\begin{array}{c}1.461 \\
(0.928)\end{array}$ & $\begin{array}{c}-1.049 \\
(0.146)\end{array}$ & $\begin{array}{c}-1.892 \\
(0.029)\end{array}$ & $\begin{array}{l}-0.400 \\
(0.344)\end{array}$ \\
\hline $\ln P O P_{i j t}$ & $\begin{array}{c}2.386 \\
(0.991) \\
\end{array}$ & $\begin{array}{c}0.888 \\
(0.813) \\
\end{array}$ & $\begin{array}{c}0.061 \\
(0.524)\end{array}$ & $\begin{array}{r}-35.282 \\
(0.000) \\
\end{array}$ & $\begin{array}{c}4.334 \\
(1.000) \\
\end{array}$ & $\begin{array}{c}-0.337 \\
(0.368) \\
\end{array}$ & $\begin{array}{c}-0.696 \\
(0.242) \\
\end{array}$ & $\begin{array}{r}-22.484 \\
(0.000) \\
\end{array}$ \\
\hline $\ln E X R_{i j t}$ & $\begin{array}{c}-0.293 \\
(0.384)\end{array}$ & $\begin{array}{c}-4.431 \\
(0.000)\end{array}$ & $\begin{array}{l}-7.286 \\
(0.000)\end{array}$ & $\begin{array}{r}-7.693 \\
(0.000)\end{array}$ & $\begin{array}{c}2.897 \\
(0.998)\end{array}$ & $\begin{array}{c}-1.225 \\
(0.110)\end{array}$ & $\begin{array}{c}-4.482 \\
(0.000)\end{array}$ & $\begin{array}{l}-3.193 \\
(0.007)\end{array}$ \\
\hline
\end{tabular}

Note: values in parenthesis are $p$-values. The results are obtained with the help of Eviews9. Source: author's own calculations.

Now, the data are at first difference, and LLC and IPS tests are applied with the same conditions (constant and constant+trend). When analyzing without the deterministic trend (only individual effects), both the LLC and IPS tests accepted the alternative hypothesis (no unit root) and rejected the null hypothesis of the usual and individual unit root in all variables except POPijt. The results based on the LLC and IPS tests strongly confirm the integration of these variables of order one (i.e., I(1)). On the other hand, when the time trend is included, all the variables become stationary, rejecting the null hypothesis of the unit root.

The overall conclusion drawn from the outcome of the LLC and IPS panel unit root tests is that there is mixed evidence of non-stationarity in all time-variant variables because some variables are stationary at level with only constant, and some are with constant + time trend. All variables become stationary when the first difference is taken for the whole panel data set and the time trend is added to the individual intercept. The interpretation of these mixed results is such that when we estimate the augmented gravity model through the OLS technique, the results will be biased and incompatible. Consequently, we cannot rely on predictions based on such biased estimates. Therefore, it is essential to ascertain a stable cointegrating (long-run) association among the variables. To determine long-run associations among the variables, Pedroni's $(1999 ; 2004)$ cointegration test is applied. The findings of the cointegration tests are summarized and explained in the next section.

\section{Findings of the Panel Cointegration Tests}

Pedroni $(1999 ; 2004)$ developed seven tests to find the long-run relationships among the variables in a panel data set. These tests are divided into two groups. The first four tests constitute the panel statistics, and the last three represent group panel statistics. The results of Pedroni's cointegration tests and Kao's t-test are reported in Table 2. 
Table 2. Panel Cointegration Tests Results

\begin{tabular}{|l|c|c|}
\hline \multicolumn{1}{|c|}{ Dependent Variable } & \multicolumn{2}{c|}{ Log of Total Trade (InTT) } \\
\hline \multicolumn{1}{|c|}{ Pedroni's Panel Statistics } & Statistic & p-value \\
\hline Panel v-Statistic & -2.8585 & 0.9979 \\
\hline Panel rho-Statistic & 1.5887 & 0.9439 \\
\hline Panel PP-Statistic & $-8.4299^{* * *}$ & 0.0000 \\
\hline Panel ADF-Statistic & $-3.1096^{* * *}$ & 0.0009 \\
\hline Group rho-Statistic & $2.5104^{* * *}$ & 0.9940 \\
\hline Group PP-Statistic & $-6.9851^{* * *}$ & 0.0000 \\
\hline Group ADF-Statistic & $-4.3739^{* * *}$ & 0.0000 \\
\hline Kao's t-Test & ADF t-Statistic & p-value \\
& $-1.247349^{* * *}$ & 0.0061 \\
\hline
\end{tabular}

Note: Results are obtained with the help of Eviews9.

Source: author's own calculation.

In the first group, among the four panel statistics, two tests, the Philips-Perron (PP) and augmented Dickey-Fuller (ADF) statistics robustly rejected the null hypothesis of no cointegration among the variables at $1 \%, 5 \%$, and $10 \%$ significance level, respectively, taking into account total bilateral trade (TT) as a dependent variable. Meanwhile, in the second group, among the three group panel statistics, two tests (group PP statistics and group ADF statistics) strongly reject the null hypothesis of no cointegration. Hence, overall, in the seven tests statistics, four tests strongly recommend that there are long-run relationships (cointegration) among the variables. These findings are also supported by Kao's t-test statistics results. Kao's t-test results demonstrate the cointegration among the variables.

In sum, long-run relationships have been found among the variables. The implication of these findings is that Pakistan's total bilateral trade significantly depends on the respective independent variables. The results of long-run relationships among the variables are generated in the next section.

\section{Estimation and Interpretation of the Long-Run Relationships}

While establishing long-run relationships among the gravity variables, panel dynamic OLS (DOLS) (Kao and Chiang 1999) and the pooled mean group (PMG) (Pesaran, Shin, and Smith 1999) are applied to the data based on bilateral trade between Pakistan and the South Asian countries. The empirical findings of thepanel DOLS and PMG models are reported in Table 3.

Model 1 represents the panel DOLS estimates, and Model 2 represents the pooled mean group estimates. The results indicate that the coefficients of all basic variables of the gravity equation follow the gravity theory of trade. The outcome of both models (panel DOLS and PMG) verify that the product of RGDPs (Pakistan's RGDP $\times$ partner RGDP) have a positive and significant impact on Pakistan's total bilateral trade. The coefficients of the RGDPs in both models are larger, but comparatively, it is very high in Model2 (the PMG model). This implies that development and growth is a long-term 
process, so as the RGDPs of both countries increase with time, their bilateral trades will also increase. The distance between two countries imposes negative effects on bilateral trade. According to our study, the distance between Pakistan and South Asian countries (normally capital cities) reduces their trade. The reason is that, as time passes, transportation costs increase, and it negatively affects Pakistan's total trade volume. Thus, trade activities, both internally (within Pakistan) and externally (outside Pakistan), exert negative changes on the country's bilateral trade volume.

Table 3. Results of Panel DOLS and Pooled Mean Group (PMG) Estimators

\begin{tabular}{|l|c|c|c|c|}
\hline \multicolumn{1}{c|}{$\begin{array}{c}\text { Dependent } \\
\text { Variables }\end{array}$} & \multicolumn{2}{c|}{ Panel DOLS } & \multicolumn{2}{c|}{ Pooled Mean Group (PMG) } \\
\cline { 2 - 5 } & \multicolumn{2}{c|}{ Model 1 } & \multicolumn{2}{c|}{ Model 2 } \\
\hline $\ln R G D P_{i j t}$ & $1.244^{* * *}$ & $(0.000)$ & $2.264^{* *}$ & $(0.015)$ \\
\hline $\ln P O P_{i j t}$ & $1.612^{* * *}$ & $(0.002)$ & $6.557^{* *}$ & $(0.041)$ \\
\hline $\ln E X R_{i j t}$ & $0.587^{* * *}$ & $(0.004)$ & $-2.134^{* * *}$ & $(0.000)$ \\
\hline $\ln D I S T_{i j}$ & $-0.856^{* * *}$ & $(0.000)$ & $-0.227^{* *}$ & $(0.030)$ \\
\hline$C B O R$ & $0.070^{* * *}$ & $(0.006)$ & $0.223^{* * *}$ & $(0.010)$ \\
\hline CLANG & $0.278^{* *}$ & $(0.015)$ & $2.099^{* *}$ & $(0.035)$ \\
\hline
\end{tabular}

Note: ${ }^{*},{ }^{* *}$, and ${ }^{* * *}$ represent significance level at $1 \%, 5 \%$ and $10 \%$ respectively. The values in parenthesis are the p-values. Results are obtained with the help of Eviews 9.

Source: author's own calculation.

The second macroeconomic variable of the gravity equation is population. The empirical results indicate that population (POP) is highly significant in both the panel DOLS and PMG techniques. The value of the coefficient suggests that a one-unit increase in population will increase the bilateral trade of Pakistan by $1.61 \%$. In the same way, the population coefficient in the PMG model is also found to be highly significant with a positive sign (6.56). This implies that one a percent increase in population will accelerate bilateral trade by approximately $6.56 \%$. The population coefficient in the PMG model is very high, indicating that population (market size) has a leading role in determining Pakistan's bilateral trade. The explanation is such that, overtime, both countries (Pakistan and the counter partner) will become self-sufficient in the production of goods and services, and hence their export capacity will increase. Its novelty is that it follows the theoretical background of the current study.

In the panel DOLS model, the coefficient of the exchange rate is found to be significant with a positive sign (0.59), indicating that in the long-run, the exchange rate has a positive impact on Pakistan's bilateral trade. These findings are against the theoretical background of this variable (exchange rate). However, these results favor expenditure switching effects; when the local currency depreciates, in turn, exports increase, ceteris paribus. In contrast to the panel DOLS results, in the PMG model, the coefficient of the exchange rate is found to be significant but with a negative sign $(-2.13)$. The exchange rate coefficient value is very large, indicating that in the long-run, the 
depreciation or appreciation of the currency brings major changes in Pakistan's bilateral trade volume.

The coefficient of distance has probable negative signs in both the panel DOLS and PMG models. The magnitudes of the coefficients in both models are different. The results of the panel DOLS model suggest that a $1 \%$ increase in distance will reduce bilateral trade by approximately $0.86 \%$. Similarly, the PMG model suggests that a $1 \%$ increase in distance will reduce bilateral trade by approximately $0.23 \%$. The coefficient sizes of distance in the panel DOLS and PMG models are very small, showing that distance has a very small impact on bilateral trade in the long-run. Both models support the theoretical background of this variable.

Besides the macroeconomic variables, two dummy variables are also incorporated in the gravity model. The common border (CBOR) is a time-invariant variable, but very sophisticated results are drawn from the estimation. The coefficient of the common border is found to be positive in both models, showing a positive impact on trade in the long-run. The coefficient size of a common border is very small (0.07) in the panel DOLS model, while in the PMG model, it is relatively high (0.22). Pakistan has common borders with India and Afghanistan. The explanation is that in the long-run, the disputes between Pakistan and India can be solved and, in turn, trade will increase between both countries. Similarly, if steps are taken to overcome terrorism, then trade between Pakistan and Afghanistan can be accelerated. However, the magnitude of coefficients in the panel DOLS and PMG models demonstrate that bilateral trade between Pakistan and border adjacent countries (India and Afghanistan) is not encouraging.

Finally, the results indicate that language similarity has a positive impact on bilateral trade. The coefficients of language are different in size in both models. The panel DOLS model suggests that Pakistan's bilateral trade is $27 \%$ greater with those countries that have language similarities. In the same way, the PMG model also demonstrates a positive relationship between language similarities and bilateral trade. The coefficient of language in the PMG model is very high, i.e., approximately $2.1 \%$, implying that, in the future, Pakistan's trade prospects are very bright with countries that share a common language.

\section{Short-Run Results of PMG Model}

Under this heading, the short-run impacts of variables on Pakistan's bilateral trade are discussed. An error correction term $\left(\mathrm{EC}_{\mathrm{t}-1}\right)$ is also incorporated in the model. The inclusion of the error correction term is intended to cover the short-run shocks (speed of adjustment) in the long-run. The short-run results of the PMG model are presented in Table 4.

The short-run findings of the PMG estimator indicate that the RGDPs of both countries (Pakistan and country $j$ ) have a very close relationship with bilateral trade in the short-run. The coefficient of RGDPij is very high (5.51) and significant at the 5\% level of significance. It means that a $1 \%$ increase in economic masses (RGDPs) of South 
Asian countries will increase Pakistan's trade volume by approximately $5.51 \%$. A high value of the RGDP coefficient demonstrates a high level of trade flows between Pakistan and the South Asian countries.

Table 4. Short-Run Results of the PMG Model

\begin{tabular}{|l|c|c|}
\multicolumn{1}{|c|}{ Dependent Variables } & Coefficients & p-value \\
\hline$\Delta \ln R G D P$ & 5.506 & 0.016 \\
\hline$\Delta \ln P O P$ & 12.638 & 0.025 \\
\hline$\Delta \ln E X R$ & -0.702 & 0.575 \\
\hline $\ln D I S T$ & -24.040 & 0.0429 \\
\hline$C B O R$ & -0.091 & 0.031 \\
\hline$C L A N G$ & 0.057 & 0.062 \\
\hline$E C T_{t-1}$ & -0.65 & 0.031 \\
\hline
\end{tabular}

Note: Results are obtained using Eviews9.

Source: author's own calculation.

Similarly, the role of market size (POP) is also crucial in determining Pakistan's bilateral trade in the short-run. Its coefficient is very large and is approximately 12.64. The results can be justified because when the home country (Pakistan) population increases, it requires more goods to immediately fulfill the needs of the rising population. Hence, imports accelerate, and the total trade volume increases.

Distance is considered a key variable in the gravity model. The coefficient of distance was found to be very high with a negative sign (-24.04). It implies that a $1 \%$ increase in distance between the trade center (capital city) of Pakistan and the other South Asian countries will reduce bilateral trade flow by $24.04 \%$. The reason is that people of both trading countries like to sell their goods in the local markets to eliminate transportation costs. Moreover, South Asian countries, including Pakistan, are basically agricultural countries, and they produce perishable goods that cannot withstand long transportation. So, to avoid losses, producers try to sell their commodities in the home markets as quickly as possible.

The coefficient of the exchange rate (EXR) is found to be insignificant with a negative sign (-0.70). The overall results signify that the exchange rate has no significant impact on Pakistan's bilateral trade flow. The empirical findings indicate that the role of a common border is not encouraging in the short-run. The findings suggest that Pakistan's trade is 9.1\% less with India and Afghanistan than other South Asian countries. Though Pakistan shares a long border with Afghanistan and India, their trade is nominal. The reasons are military conflicts on the line of control with India and political suspicions between Pakistan and Afghanistan.

The coefficient of a common language is positive and significant at the $10 \%$ level of significance. The estimated coefficient is very small, indicating that language similarities have small impact on bilateral trade between Pakistan and its trading part- 
ners. The results suggest that Pakistan's trade is 5.7\% greater with countries that have language similarities. The reason is that people of both Pakistan and its trading partner countries quickly and easily understand their business language, facilitating trade activities. These findings are similar to the studies of Roy and Rayhan (2011) and Gul and Yasin (2011).

The main objective of the short-run analysis was to find out the coefficient of error correction term (ECTt-1). The error correction term measures short-run shocks or disequilibrium in the bilateral trade flow. The empirical findings of the current study indicate that the coefficient of ECTt-1 has the expected sign $(-0.65)$ and significance at the $5 \%$ level of significance. The ECT also denotes the speed of adjustment. The result implies that if there is disequilibrium in the short-run or any divergence from the long-run in the preceding year, then it will be corrected by $65 \%$ in the current year. In other words, if Pakistan faces short-run losses or trade deficits with its trading partners, then $65 \%$ of its losses can be covered in the present year.

\section{Conclusion}

This research study was conducted to analyze the bilateral trade between Pakistan and South Asian countries by using a gravity model of trade. Thereis a long history of applied research where the gravity model is used to examine the bilateral trade patterns and trade relationships (see Poyhonen 1963; Bergstrand 1985; Koo and Karemera 1991; Oguledo and Macphee 1994; Zhang and Kristensen 1995; Mathur 1999; Paas 2000; Hassan 2001; Kalbasi 2001; Christie 2002; Akhter and Ghani 2010; Nguyen 2010; Wang et al. 2010; Gul and Yasin 2011; Malik and Chaudhary 2012; Panda and Kumaran 2016). In the above studies, the researchers analyzed only large countries in the region. Moreover, very little work has been done on the trade patterns of south Asian countries. In this paper, we analyzed Pakistan's bilateral trade with all South Asian countries, regardless of whether they are large or small. The degree of trade integration among the regional countries is quantified in a very sophisticated way. The role of all basic gravity variables in the long-run and short-run are justified both theoretically and empirically. The novelty of this study is that it measures the impacts of qualitative variables (common border and common language) along with the use of quantitative variables (GDP, POP \& EXR).

Various econometric techniques were used for the empirical analysis. Panel unit root tests (LLC \& IPS) were applied to remove the problem of the unit root. The findings of the LLC and IPS tests indicate that some variables are stationary at level while others are at first difference. Based on the mixed evidence of the panel unit root tests, Pedroni's cointegration test was applied. The outcome suggested that all variables are cointegrated and that long-run relationships exist among the variables. To capture the extent of these long-run relationships, pooled mean group (PMG) and panel dynamic ordinary least square (DOLS) models were estimated. The results of the PMG 
and Panel DOLS models indicate that the economic mass (RGDP) and market size (population) of Pakistan and the other south Asian countries have a positive impact on their bilateral trade. The reason is that when population growth increases, they import more goods according to their needs. The distance between Pakistan and the other trading partners has a negative impact on bilateral trade because more distance means more transportation costs. The findings indicate that exchange rate has a negative sign in the PMG model and a positive sign in the Panel DOLS model. Pakistan has common borders with India and Afghanistan, but their trade is insignificant. The reasons are historical disputes and military conflicts. Similarly, terrorism and political suspicions between Pakistan and Afghanistan hinder their trade.

The novelty of the PMG model is that it gives short-run results. The findings suggested that RGDP and population have usual (positive) effects. The coefficient of distance is very large and negative in the short-run. The reason is that, in the short-run, people prefer to put their goods in the local market due to high transportation costs. The coefficient of the exchange rate is negative and insignificant. It means that the exchange rate has no impact on Pakistan's trade in the short-run. A common border has a negative coefficient, but its impact is very small. The coefficient of the error correction term, which measures short-run shocks, has the expected sign. This is justified as: if Pakistan faces short-run losses or trade deficits with its trading partners, then 65\% of its losses can be covered in the present year.

\section{References}

Akhter, N., Ghani, E. (2010), Regional Integration in South Asia: An Analysis of Trade Flows Using the Gravity Model, “The Pakistan Development Review”, 49 (2), pp. 105118. https://doi.org/10.30541/v49i2pp.105-118

Baltagi, B.H. (2008), Econometric Analysis of Panel Data (Fourth Edition), John Wiley\& Sons, Chichester. https://www.worldcat.org/title/econometric-analysis-of-panel-da ta/oclc/191753150 (accessed: 23.04.2018).

Bergstrand, J.H. (1985), The Gravity Equation in International Trade: Some Microeconomic Foundations and Empirical Evidence, "The Review of Economics and Statistics”, 67, pp. 474-81. https://doi.org/10.2307/1925976

Christie, E. (2002), Potential Trade in Southeast Europe: A Gravity Model Approach, Working Paper, The Vienna Institute for International Economic Studies. http:// hdl.handle.net/10419/203886 (accessed: 12.12.2018).

Fidrmuc, J. (2009), Gravity Models in Integrated Panels, "Empirical Economics", 37, pp. 435-446. https://doi.org/10.1007/s00181-008-0239-5

Frank, M.W. (2007), Estimation of Non-Stationary Heterogeneous, “The Stata Journal”, 7 (2), pp. 197-208. https://doi.org/10.1177/1536867X0700700204

Gul, N., Yasin, H.M. (2011), The Trade Potential of Pakistan: An Application of the Gravity Model, "Lahore Journal of Economics", 16 (1), pp. 23-62. https://doi.org/10 .35536/lje.2011.v16.i1.a2 
Hassan, M.K. (2001), Is SAARC a Viable Economic Block? Evidence from Gravity Model, "Journal of Asian Economics", 12, pp. 263-290. https://doi.org/10.1016/S1049-00 78(01)00086-0

Im, K.S., Pesaran, M.H., Shin, Y. (2003), Testing for Unit Roots in Heterogeneous Panels, "Journal of Econometrics", 115, pp. 53-74. https://doi.org/10.1016/S0304-4076 (03)00092-7

Kao, C. (1999), Spurious regression and Residual-Based Tests for Cointegration in Panel Data, "Journal of Econometrics", 90, pp. 1-44. https://doi.org/10.1016/S0304-40 76(98)00023-2

Koo, W.W., Karemera, D. (1991), Determinants of World Wheat Trade Flows and Policy Analysis, "Canadian Journal of Agricultural Economics", 39, pp. 439-455. https:// doi.org/10.1111/j.1744-7976.1991.tb03585.x

Krugman, P.R., Obstfeld, M., Melitz, J.M. (2012), International Economics: Theory and Policy, $9^{\text {th }}$ Edition, Addison-Wesley, Boston. https://www.amazon.com/Internationa 1-Economics-Theory-Policy-9th/dp/0132146657 (accessed: 26.12.2017).

Kumar, N. (2005), Globalization and the quality of foreign direct investment, Oxford University Press, New Delhi-New York.

Levin, A., Lin, C.F., Chu, C. (2002), Unit Root Test in Panel Data: Asymptotic and Finite Sample Properties, "Journal of Econometrics”, 108, pp. 1-25. https://www.scirp .org/reference/ReferencesPapers.aspx?ReferenceID=2340559 (accessed: 18.06.2017).

Malik, S., Chaudhary, A.R. (2012), The Structure and Behavior of Pakistan's Imports from Selected Asian Countries: An Application of Gravity Model, "Pakistan Journal of Commerce Social Science”, 6 (1), pp. 53-66. http://www.jespk.net/publication_pa per.php?publicationid=11 (accessed: 3.04 .2018 ).

Mathur, S.K. (1999), Pattern of International Trade, New Trade Theories and Evidence from Gravity Equation Analysis, “The Indian Economic Journal”, 47 (4), pp. 68-88.

Mohmand, Y.T., Wang, A. (2013), The Gravity Of Pakistan's Export Performance In Stratified Sampling, "Pakistan Journal of Statistics", 29 (2), pp. 203-216. https:// www.researchgate.net/publication/286481873_The_gravity_of_Pakistan's_export _performance_in_stratified_sampling (accessed: 20.07.2018).

Newfarmer, R., Pierola, M.D. (2006), SAFTA: Promise and Pitfalls of Preferential Trade Arrangements, The World Bank, Washington.

Nguyen, B.X. (2010), The Determinants of Vietnamese Export Flows: Static and Dynamic Panel Gravity Approaches, "International Journal of Economics \& Finance", 2 (4), pp. 122-129. https://doi.org/10.5539/ijef.v2n4p122

Oguledo, V.I., Macphee, C.R. (1994), Gravity Models: A Reformulation and an Application to Discriminatory Trade Arrangements, "Applied Economics”, 26, pp. 107-120. https://doi.org/10.1080/00036849400000066

Paas, T. (2000), Gravity Approach for Modeling Trade Flows between Estonia and the Main Trading Partners, Working Paper, No. 721, Tartu University Press, Tartu.

Panda, R., Kumaran, M. (2016), A Study of Bilateral Trade Flows of China and India, "Indian Journal of Science and Technology", 9 (15), pp. 01-07. https://doi.org/10.17 485/ijst/2016/v9i15/92098

Pedroni, P. (1999), Critical Values for Cointegration Tests in Heterogeneous Panels with Multiple Regressors, “Oxford Bulletin of Economics and Statistics”, 61, pp. 653-678. 
https://web.williams.edu/Economics/wp/pedronicriticalvalues.pdf (accessed: 17.08. 2018).

Pedroni, P. (2004), Panel Cointegration: Asymptotic and Finite Sample Properties of Pooled Time Series Tests with an Application to the PPP Hypothesis, "Econometric Theory”, 20, pp. 597-625. https://doi.org/10.1017/S0266466604203073

Pesaran, M.H., Shin, Y., Smith, R.P. (1999), Pooled Mean Group Estimation of Dynamic Heterogeneous Panels, "Journal of the American Statistical Association", 94, pp. 621-634. http://dx.doi.org/10.1080/01621459.1999.10474156

Poyhonen, P. (1963), A Tentative Model for the Volume of Trade between Countries, "Welt wirtschaftliches Archiv", 90, pp. 93-100. http://www.jstor.org/stable/4043 6776 (accessed: 7.04.2017).

Rispens, R.K.E. (2009), Modern Economic Growth Theories and the "Miracle" of the East Asian Tigers, Erasmus University Rotterdam, School of Economics, Rotterdam. https://thesis.eur.nl/pub/6437/Rispens\%2C\%20R.302857\%20-\%20id\%20the sis6437.pdf (accessed: 13.11.2018).

Roy, M., Rayhan, M.I. (2011), Trade Flows of Bangladesh: A Gravity Model Approach, "Economics Bulletin", 31 (1), pp. 950-959. https://ideas.repec.org/a/ebl/ecbull/eb-11 -00050.html (accessed: 19.03.2018).

Saikkonen, P. (1991), Asymptotically Efficient Estimation of Cointegrating Regressions, "Econometric Theory", 7, pp. 1-21. https://doi.org/10.1017/S0266466600004217

Stock, J.H., Watson, M.W. (1993), A Simple Estimator of Cointegrating Vectors in Higher Order Integrated Systems, “Econometrica”, 61 (4), pp. 783-820. https://doi.org/10 $.2307 / 2951763$

Tinbergen, J. (1962), Shaping the World Economy: Suggestions for an International Economic Policy, Twentieth Century Fund, New York.

Waheed, A., Abbas, S. (2015), Potential Export Markets for Bahrain: A Panel Data Analysis, "International Journal of Trade, Economics and Finance", 6 (3), pp. 165-169. https://doi.org/10.7763/IJTEF.2015.V6.463

Wang, C., Wei, Y., Liu, X. (2010), Determinants of bilateral trade flows in OECD countries: evidence from gravity panel data models, "The World Economy", 33 (7), pp. 894-915. https://doi.org/10.1111/j.1467-9701.2009.01245.x

Wang, J. (2016), Analysis and Comparison of the Factors Influencing Worldwide Four Kinds of Vegetable Oil Trade: Based on Gravity Model, "Modern Economy", 7 (2), pp. 173-182. https://doi.org/10.4236/me.2016.72019

Wilson, J.S., Otsuki, T. (2007), Regional Integration in South Asia: What Role for Trade Facilitation? World Bank Policy Research, Working Paper, No. 4423. https://doi.org /10.1596/1813-9450-4423

World Bank (2017), World Development Indicators. http://data.worldbank.org/data-c atalog/world-development-indicators (accessed: 19.12.2018).

Zhang, J., Kristensen, G. (1995), A Gravity Model with Variable Coefficients: The EEC Trade with Third Countries, "Geographical Analysis", 27, pp. 307-320. https://doi .org/10.1111/j.1538-4632.1995.tb00913.x 


\section{Streszczenie}

\section{Analiza panelowa grawitacji handlu między Pakistanem a krajami Azji Południowej}

W artykule podjęto próbę zbadania wzorców handlowych widocznych w relacjach $\mathrm{Pa}$ kistanu z krajami Azji Południowej przy użyciu grawitacyjnego modelu handlu. Głównym celem badania było ilościowe określenie długoterminowego wpływu zmiennych grawitacyjnych. Aby osiągnąć ten cel, wykorzystano zestaw danych panelowych dla lat 2003-2017. Ponieważ wyniki testów panelowych pierwiastka jednostkowego były niewiarygodne, zastosowano techniki Pooled Mean Group (PMG) i Panel Dynamic Ordinary Least Square (DOLS). Wyniki modeli PMG i Panel DOLS uzasadniają teoretyczne podstawy modelu grawitacyjnego i sugerują, że wszystkie podstawowe zmienne grawitacyjne mają typowe znaki. Realny PKB i liczba ludności zarówno Pakistanu, jak i kraju partnerskiego mają pozytywny wpływ na ich handel dwustronny. Z drugiej strony odległość między dwoma krajami dokonującymi wymiany handlowej oraz kurs walutowy mają negatywny wpływ na handel dwustronny. Wyjątkowość tego badania polega na tym, że mierzy ono jednocześnie wpływ zmiennych jakościowych oraz podstawowych zmiennych grawitacyjnych. Podobieństwa językowe i wspólne granice mają pozytywny wpływ na handel dwustronny. Jednakże, choć Pakistan graniczy z Indiami i Afganistanem, ich relacje handlowenie są istotne. Konflikty zbrojne między Pakistanem a Indiami oraz polityczna podejrzliwość w relacjach Pakistanuz Afganistanem komplikują ich stosunki handlowe.

Słowa kluczowe: Azja Południowa, Pakistan, model grawitacyjny, kurs walutowy, liczba ludności 